\title{
Technology and function of grooved abraders in the early Neolithic of northwestern Europe
}

\author{
Caroline Hamon \\ Centre National de la Recherche Scientifique (CNRS), UMR 8215 Trajectoires, Maison de l'archéologie, 21 \\ allée de l’Université 92023 Nanterre cedex, France. Email: caroline.hamon@mae.cnrs.fr
}

\begin{abstract}
:
Found sporadically in late Palaeolithic and Mesolithic contexts, grooved abraders are among the most common tools found in Linear Pottery and Villeneuve-Saint-Germain settlements in northwestern Europe (5,100-4,700 BCE). This paper presents an overview of the technical and functional characteristics of these tools in early Neolithic domestic contexts. Despite different blank morphologies and sizes, these tools tend to be relatively small in size and are generally not shaped. They are characterized by the use of a very specific raw material: low cohesive and generally ferruginous sandstones, chosen because their abrasiveness is enhanced through use. A classification of the different types of grooves is proposed, based on their shape, depth, section and localization. These characteristics are combined with use-wear analysis in order to propose a number of functional interpretations. Far from the widespread hypothesis that these tools functioned as shaft straighteners, we argue on the basis of the use-wear analysis and archaeological associations of items that these tools were primarily involved in the manufacture of bone and lithic tools, as well as of schist and limestone personal ornaments. They are evidence of the generalization and diversification of polishing and abrading techniques in the technical system of the first Neolithic populations. As such, they contribute to defining a whole new technical paradigm and are an essential element in any definition of the Neolithic.
\end{abstract}

Keywords: grooved abraders; Neolithic; Western Europe; technology; function; ground stone tools

\section{Introduction}

The definition of "grooved abraders" covers a wide diversity of types found all around the world and in very varied chrono-cultural contexts, from Africa (Huard 1966; Gaussen \& Gaussen 1988), to the Middle East (Solecki \& Solecki 1970; Balkan-Atli 1994; Aurenche \& Koslowski 1999: 65 ; Christensen \& Valla 1999; Rosenberg et al. 2012; Molist et al. 2013) and the central Asian steppes (Usacheva 2013). These ethnographic examples document the use of such abraders for different activities, especially the shaping of mineral and vegetal objects. The use of long grooves with U-shaped cross section has been described for straightening arrow shafts in hunter-gatherer societies such as the Bushmen (Dunn 1931: 69-

Published by the School of History, Classics and Archaeology, University of Edinburgh ISSN: 2055-0472. URL: http://journals.ed.ac.uk/lithicstudies/

This work is licensed under a Creative Commons Attribution 2.5 UK: Scotland License. 
70) or the Plains Indians (Flenniken \& Ozbun 1998; Adams 2002: 82-87), to take but two examples. The use of grooved abraders for the shaping of strung circular beads has also been documented in northern Africa (Camps-Fabrer 1960; Huard 1966). Based on these ethnographic parallels, the function of these implements has long been limited to one or two hypotheses.

In Europe, grooved abraders are known since the late Palaeolithic (De Beaune 2000: 105108), and are found regularly on Mesolithic occupation sites (Rozoy 1978: 973-975; Gob \& Pirnay 1980; Loftus 1982; Bolus 2012). They show an astonishing homogeneity of raw materials, morphology and dimensions throughout a long period of time, a fact which cannot be explained without taking their status and function into account. Our technological and functional study of the different grooved abraders from several early Neolithic sites in Western Europe led us to re-evaluate the exact function of these tools. We argue that in the new technical system that developed with the Neolithic, grooved abraders were involved in more varied activities and technical operations than during the previous periods, illustrating diversification in the use of grinding and polishing techniques for a wide range of tasks.

\section{Materials and methods}

The introduction of a Neolithic economy in northwestern Europe is dated between 5,100 and 4,700 BCE cal. It is characterised by the settling of farming populations in typical longhouses organised in villages. In these contexts, most of the archaeological artefacts come from refuse assemblages, found in the lateral pits bordering these houses. Their composition accurately reflects the functioning of the household (Allard et al. 2013; Gomart et al. 2015).

Among other activities, the daily processing and consumption of cereals is materialized by the ubiquity of grinding tools within the village. Other important technical innovations are part of the linear pottery package, such as the use of abrasion for the manufacture of stone and bone tools, or of typical shell, schist and limestone ornaments. The production of ceramic also requires tempering material, made of crushed bone, flint, and crushed pottery. Such emblematic material production of the first farming populations in Western Europe required technological developments of the stone equipment that archaeologists have traditionally referred to as macrolithic tools. Relying on the analysis of about 1400 of these macrolithic tools, from 20 Linear Pottery sites and 23 Villeneuve-Saint-Germain sites in northern France and Belgium, our research allows an overview of their role in subsistence and craft activities.

Abraders are among the most common tools found in these contexts, where abrasion and polishing techniques are widely used for the manufacture of personal ornaments, axes and bone tools (Hamon 2006: 57-58; 2008). A complete analysis was conducted on 114 abrading and polishing tools from 13 of these sites (Table 1; Figure 1). It took into account not only the selection of their raw material, the morphology of their blanks and grooves and their shaping sequence, but also their use-wear analysis.

Depending on the origin (site, year of excavation), storage conditions and raw material cohesion, the tools were cleaned by a simple hand washing in water or by soft brushing, in some cases completed with a more accurate secondary cleaning. This analysis was primarily based on a low power approach, up to 90x magnification using a stereomicroscope (Nikon SMZ 800), following a dedicated framework developed for macrolithic tools. This methodology relies on the characterisation of several use-wear traces on heterogeneous rocks, including grain extractions and microfractures, degree of levelling of the microtopography, edge rounding of the grains, and development of a micropolish or sheen (Hamon 2006; Adams et al. 2009).

Interpretation of the tool's function after use-wear analysis relied on comparisons with a wider experimental referential $(n=92)$ developed for the analysis of sandstone macrolithic 
tools used for craft and food activities in early Neolithic contexts in western Europe (Hamon 2008). For the use-wear analysis of early Neolithic abraders, comparisons were more particularly established with experimental tools used for the manufacturing of shell ornaments $(n=4)$, limestone beads $(n=10)$, schist bracelets $(n=10)$, as well as for the shaping of wood $(n=7)$, bone $(n=12)$ and antler tools $(n=8)$, or flint axes $(n=2)$.

Table 1. Number and types of abraders studied for the early Neolithic of western Europe.

\begin{tabular}{|c|c|c|c|c|c|}
\hline Site & 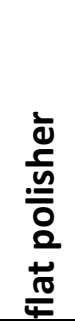 & 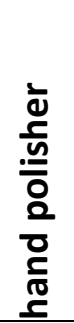 & $\begin{array}{l}\frac{1}{0} \\
\frac{0}{0} \\
\frac{0}{0} \\
\frac{0}{0} \\
\frac{0}{0} \\
\frac{0}{60}\end{array}$ & 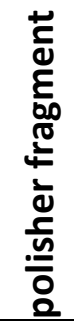 & publication \\
\hline Berry-au-Bac - le Vieux Tordoir & & & & 5 & Hamon 2006 \\
\hline Cuiry-les-Chaudardes - les Fontinettes & & & 28 & & Hamon 2006 \\
\hline Bucy-le-Long - la Fosselle & 1 & & & 8 & Hamon 2006 \\
\hline Bucy-le-Long - le Fond du Petit Marais & 1 & 1 & & & Hamon 2006 \\
\hline Bucy-le-Long - la Fosse Tounise & & & 1 & 4 & Hamon 2006 \\
\hline Trosly-Breuil - les Obeaux & & 4 & & 5 & Hamon 2006 \\
\hline Ocquerre - la Rocluche & 3 & 2 & 6 & & Hamon 2009 \\
\hline Colombelles - Le Lazzarro & 1 & 2 & 3 & & Billard et al. 2014 \\
\hline Betton - Pluvignon & 1 & 6 & 1 & & Blanchet et al. 2010 \\
\hline Remicourt - En Bia Flo II & 3 & 5 & 3 & & Hamon \& Goemaere 2007 \\
\hline Fexhe - Le Haut Clocher & 1 & & 4 & & Hamon \& Goemaere 2007 \\
\hline Oleye - Al Zèpe & 1 & 7 & 3 & & Hamon \& Goemaere 2007 \\
\hline Waremmes-Longchamps & 1 & 3 & & & Hamon \& Goemaere 2007 \\
\hline TOTAL & 13 & 30 & 49 & 17 & \\
\hline
\end{tabular}

Through this paper, we propose a critical synthesis of the role of grooved abraders within the early Neolithic technical system, relying on a renewed techno-functional classification of the different tool types. Focusing on previously published examples, we demonstrate that far from a homogeneous toolkit, grooved abraders contribute to different tasks and craft activities.

\section{Results}

\subsection{Raw material}

The grooved abraders analyzed were always made using the same kind of raw material. Whatever their geological origin, the chosen sandstones share the same characteristics. They generally exhibit a low level of cementing and cohesion and are composed of quartz grains together with ferruginous and glauconitic inclusions. Such properties provide systematically sharp grains and a high degree of surface abrasiveness. In addition, the grains frequently detach and interact with the transformed matter as an additive, in the same way as sand, for example. The grains composing these sandstones are quite well-sorted, which is a condition for obtaining regular and homogeneous surfaces during the abrading operation of the worked piece. 
The combination of all these characteristics clearly highlights the fact that maximum rugosity and abrasiveness of the surfaces were sought-after properties, together with permanent efficiency due to the constant removal of the grains and surface renewal. Consequently, the use-wear traces are constantly being removed from the surfaces together with the grains themselves. This explains the low intensity of development of the traces observable microscopically and also explains the limits and difficulties involved in developing use-wear analysis for such tools. The current study of grooved abrader function will focus primarily on examples made from more cohesive sandstones.

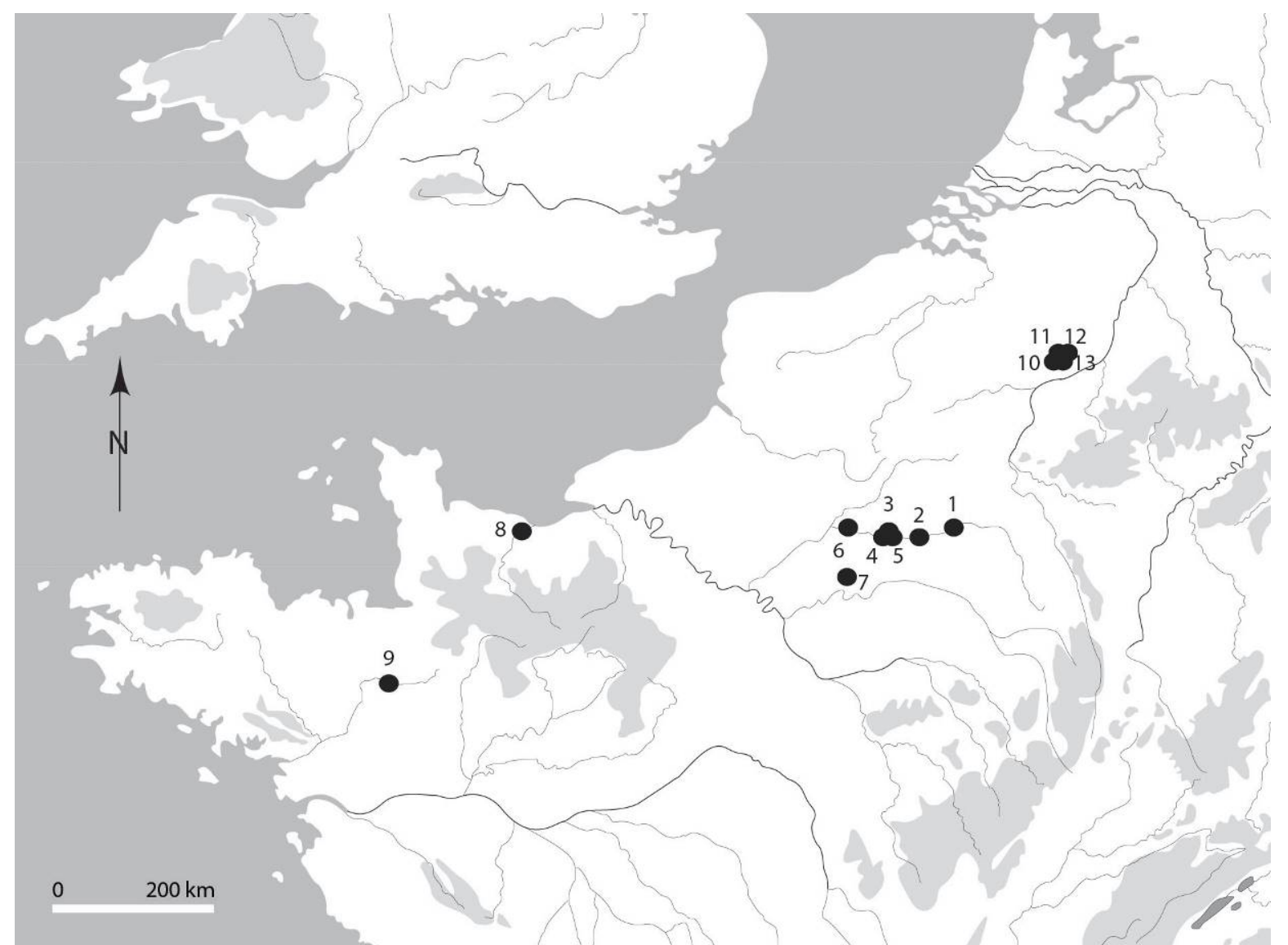

Figure 1. Map of the 13 sites where the study of the macrolithic tools was conducted: a. Berry-au-Bac - le Vieux Tordoir; 2. Cuiry-les-Chaudardes - les Fontinettes; 3. Bucy-le-Long - la Fosselle; 4. Bucy-le-Long - le Fond du Petit Marais; 5. Bucy-le-Long - la Fosse Tounise; 6. Trosly-Breuil - les Obeaux; 7. Ocquerre - la Rocluche; 8. Colombelles - Le Lazzarro; 9. Betton - Pluvignon; 10. Remicourt - En Bia Flo II; 11. Fexhe - Le Haut Clocher; 12. Oleye - Al Zèpe; 13. Waremmes-Longchamps.

Most of these kinds of sandstones are available locally, within a radius of 5 to $10 \mathrm{~km}$ from the sites: this is especially the case in the Paris Basin where Thanetien sand stone levels were frequently exploited and easily accessible (see Figure 2) (Hamon 2006: 18). In the Armorican Massif, Brioverien and "roussard" (reddish) sandstones are the preferred raw materials for grooved abraders, and they display diversity in their granulometry and sorting (see Figure 3) (Gaumé 2007; Billard et al. 2014: 246-247).

Some specific cases should be noted. When grooves are associated with other working surfaces, which may or may not have been for abrading operations, the raw material may be of different quality. In this case, more cohesive sandstones are generally involved. In the same way, certain objects made of abraded hematite also show occasional grooves on some of their sides (Billard et al. 2014: 256-257). 

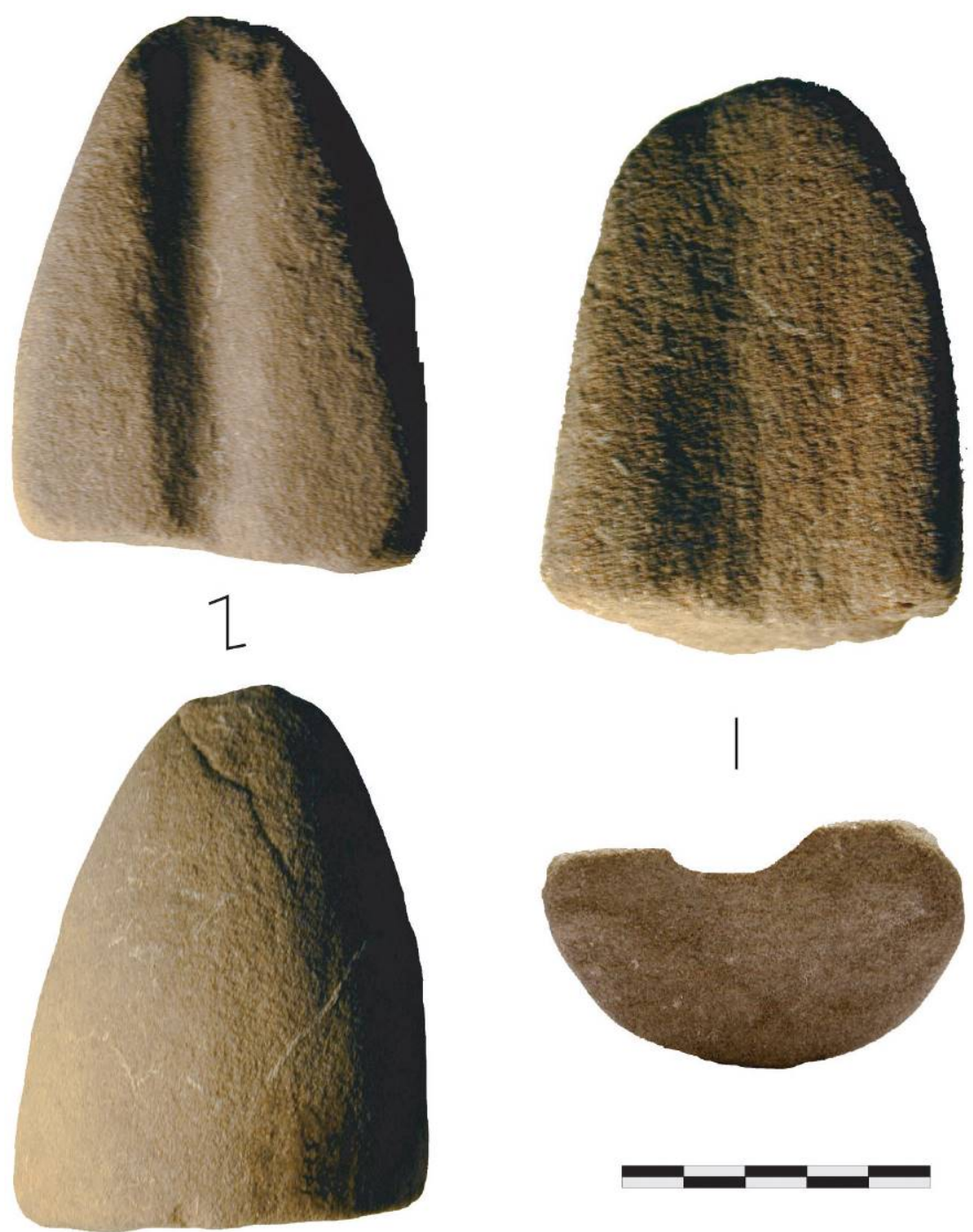

Figure. 2. Comparison of two longitudinally grooved abraders in Thanetien sandstone from Trosly-Breuil «les Obeaux» (Oise) and from the Linear Pottery site of Etigny "le Brassot-est” (Yonne) (after Allard et al. 2006).
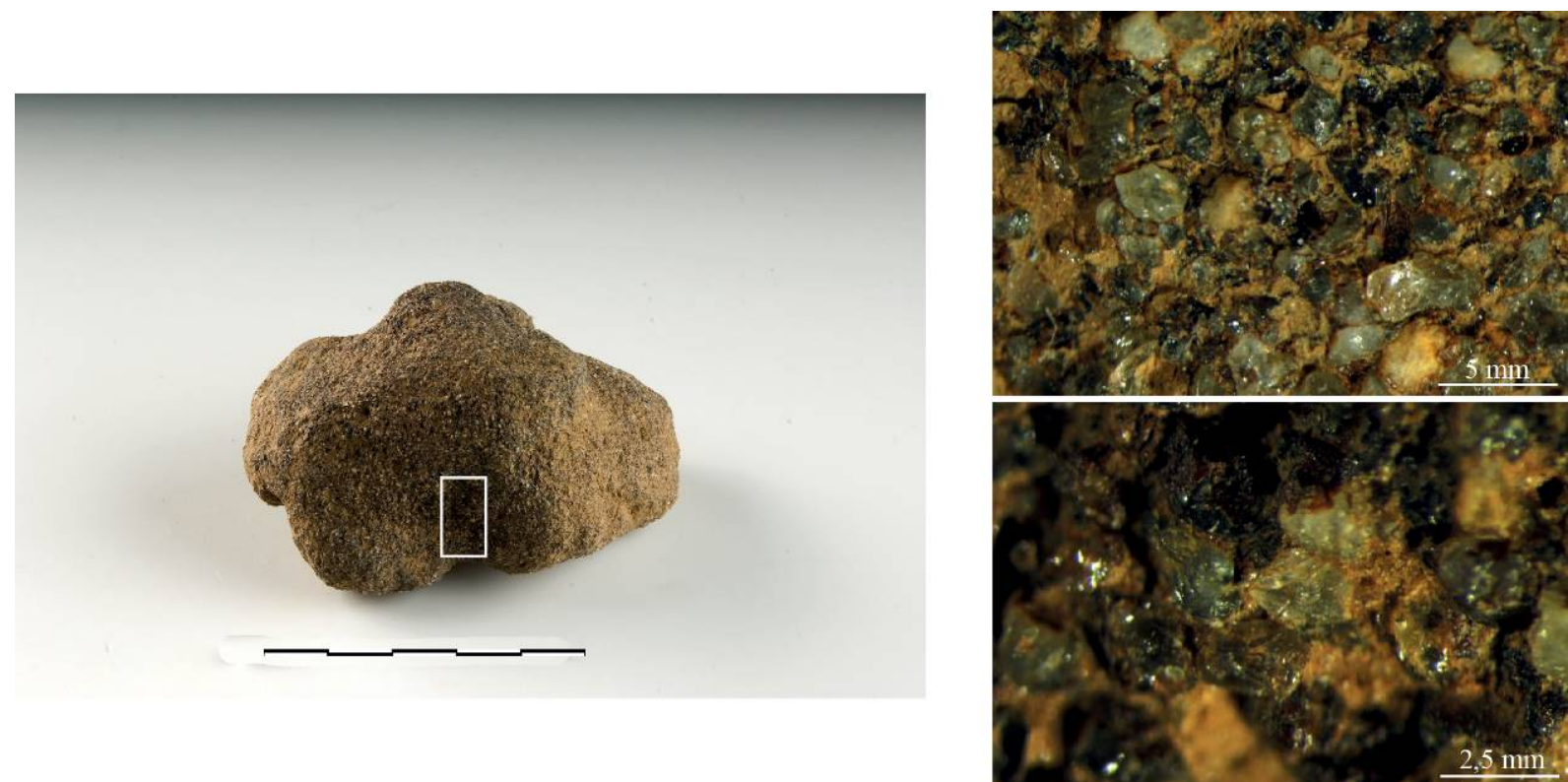

Figure 3. Grooved abrader in "roussard" sandstone found on the schist bracelet workshop in Arçonnay (Sarth). Scale bar in the left photo is $5 \mathrm{~cm}$. 


\subsection{Morphology}

In western European early Neolithic contexts, grooved abraders are made using a wide range of different blanks, to the extent that it appears that the morphology of the blocks and fragments used plays absolutely no role in their selection.

The fragments tend to be small in size, generally between 5 and $10 \mathrm{~cm}$. The working surfaces generally associate a large surface of abrasion with a more or less centred groove created either by shaping or use. The morphologies of these working surfaces are diverse, varying from concave to convex. They are characterized by intensive use of the available surfaces, as most of the tools show several working surfaces and grooves on several of their faces. This underlines the fact that the raw material was sought after and its use was optimized.

Within the wide range of grooved abraders recorded, it is evident that certain specific types of blanks were sometimes selected. For example, on the site of Menneville, which is located tens of kilometres from the available outcrops of glauconious sandstones (the usual raw material used in the Aisne valley, France), several grooved abraders were made using quartzitic sandstone flakes, which was selected from the refuse of the first stages of quern shaping (Figure 4) (Allard et al. 2006).

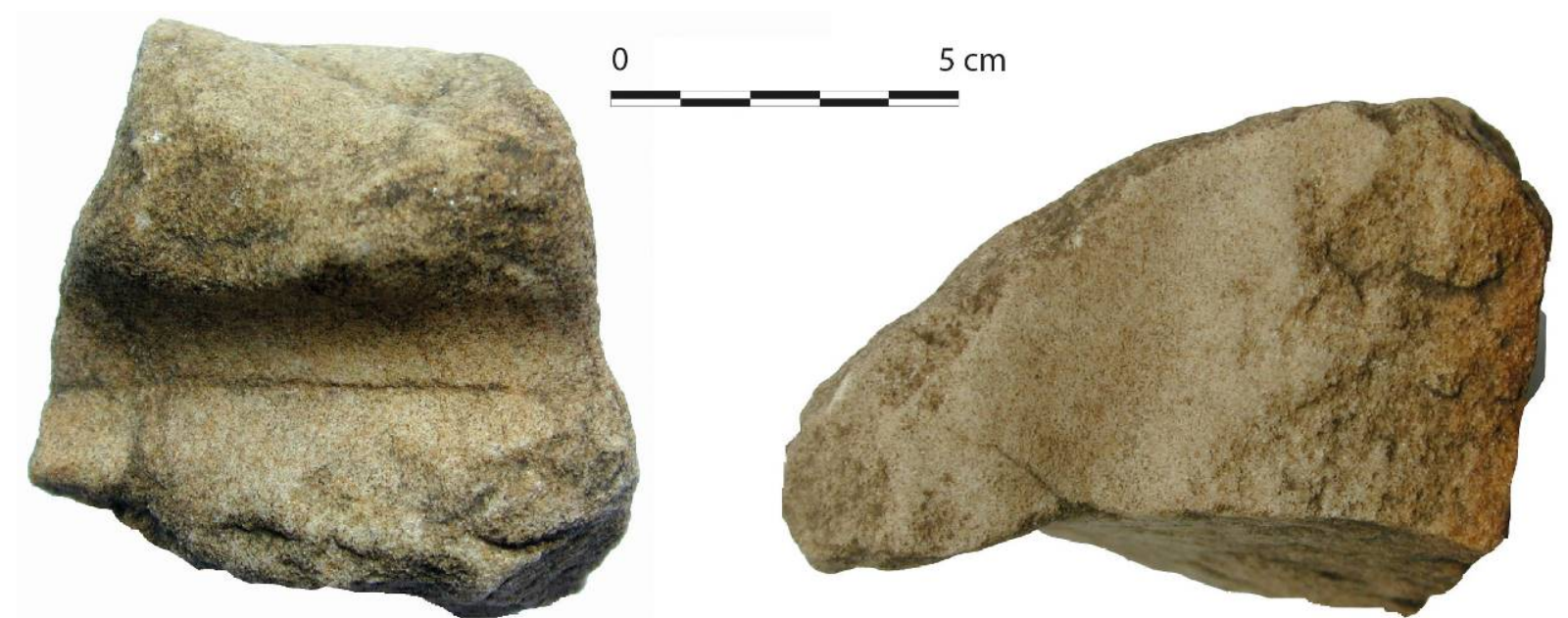

Figure 4. Examples of grooved abraders in Menneville (Aisne Valley) made on flakes from quern shaping which were opportunistically chosen as blanks.

One type of abrader is characterized by a specific morphology and dimensions of the entire tool as well as of the groove itself. Two examples of this type of abrader, one from the Linear Pottery site of Etigny "le Brassot-est" (Yonne valley) and another from the Villeneuve-Saint-Germain site of Trosly-Breuil“ les Obeaux” (Aisne valley) are very similar in morphology (Figure 2) (Allard et al. 2006). They are semi-oval in shape, semi-circular in section, and feature a central longitudinal groove, with parallel sides and an open "u" section. This category may correspond to grooved abraders used in hunting-gathering contexts and may be interpreted as shaft straighteners. However, their probable function cannot in itself explain such a morphological and technological standardisation, which could also be related to their particular, maybe cultural, status.

\subsection{Shaping}

Most of the grooved abraders show no traces of shaping, an observation which fits with the high degree of variability in tool morphology. However, within a specific category of abraders, it is clear that there was a certain degree of "standardization" in terms of their shape, 
dimensions and surface treatment, which was obtained by intentional shaping. As shown by the technological study, the back and sides of these abraders were shaped using fine pecking and regularized by polishing, in order to obtain a regular semi-circular section.

One of the main questions is whether or not the grooves were pre-formed prior to use. The main face was polished so as to obtain a flat surface. But the groove itself was probably pre-formed, as attested by frequent traces of fine pecking still visible under the use-wear traces on their lowest part. This pecking, at least in some cases, was used to produce a regular and standardized cross section.

Such treatment of grooved abraders can be explained in two ways. First, these types of abraders were sometimes used in pairs, as suggested by their deposition in tombs (Farruggia 1992: 41), and, therefore, required a certain degree of standardization in order to function efficiently together. Second, their deposition in tombs also suggests that these tools were personal property and that a certain status was attached to the activities for which they were used.

\subsection{Classification of the grooves}

A classification of the different types of grooves can be proposed, based on their shape, depth, localization and orientation (Figure 5):

- one or more curvilinear, crossing grooves of various lengths and orientations (Figure 5a) short, wide grooves, generally parallel and located on a single face(length less than $5 \mathrm{~cm}$, width up to $2 \mathrm{~cm}$ ) (Figure $5 \mathrm{~b}$ );

- a single, narrow, centrally-placed, longitudinal groove (width less than $0.5 \mathrm{~cm}$ ) (Figure 5c);

- one or groups of pointed grooves with different orientations, the wide base of these grooves is located on the edge of the abrader (Figure 5d-e);

- a single, large, u-section, centrally-placed, longitudinal groove (Figure 2).

Such variety in groove-shape and localization clearly reflects diversity in some aspects of their use for shaping of hard or semi-hard materials. Furthermore, the morphological and technical characteristics of these tools indicate a lower- (or passive-) use for most of these abraders. However, in some cases, it is impossible to determine whether these hand-held abraders were used solely in a passive position (i.e. with the object to transform being rubbed against an abrader), rather than in an active one (i.e. the abrader being rubbed against the object to transform). Both gestures may have been used.

\subsection{Use-wear analysis and function}

By focusing on several examples of use-wear analysis on different types of grooved abraders, we propose to reconsider their function in the context of the domestic activities carried out by the first farmers.

As a first example, the use-wear analysis of early Neolithic grooved abraders associated with the production of beads and bracelets shows that these tools were used for different tasks and operations.

A set of three grooved abraders were found in two pits associated with a house on the Linear Potterysite (RRBP phase) of Marolles-sur-Seine "le chemin de Sens" (Seine valley, Augereau \& Bonnardin 1998). Within the pits, these abraders were associated with 163 circular shell and limestone bead roughouts, some of which were found inside a pottery vessel, and 213 drills made out of flint. This assemblage was clearly part of a workshop for the production of personal ornaments associated with one specific domestic unit (Figure 6). 

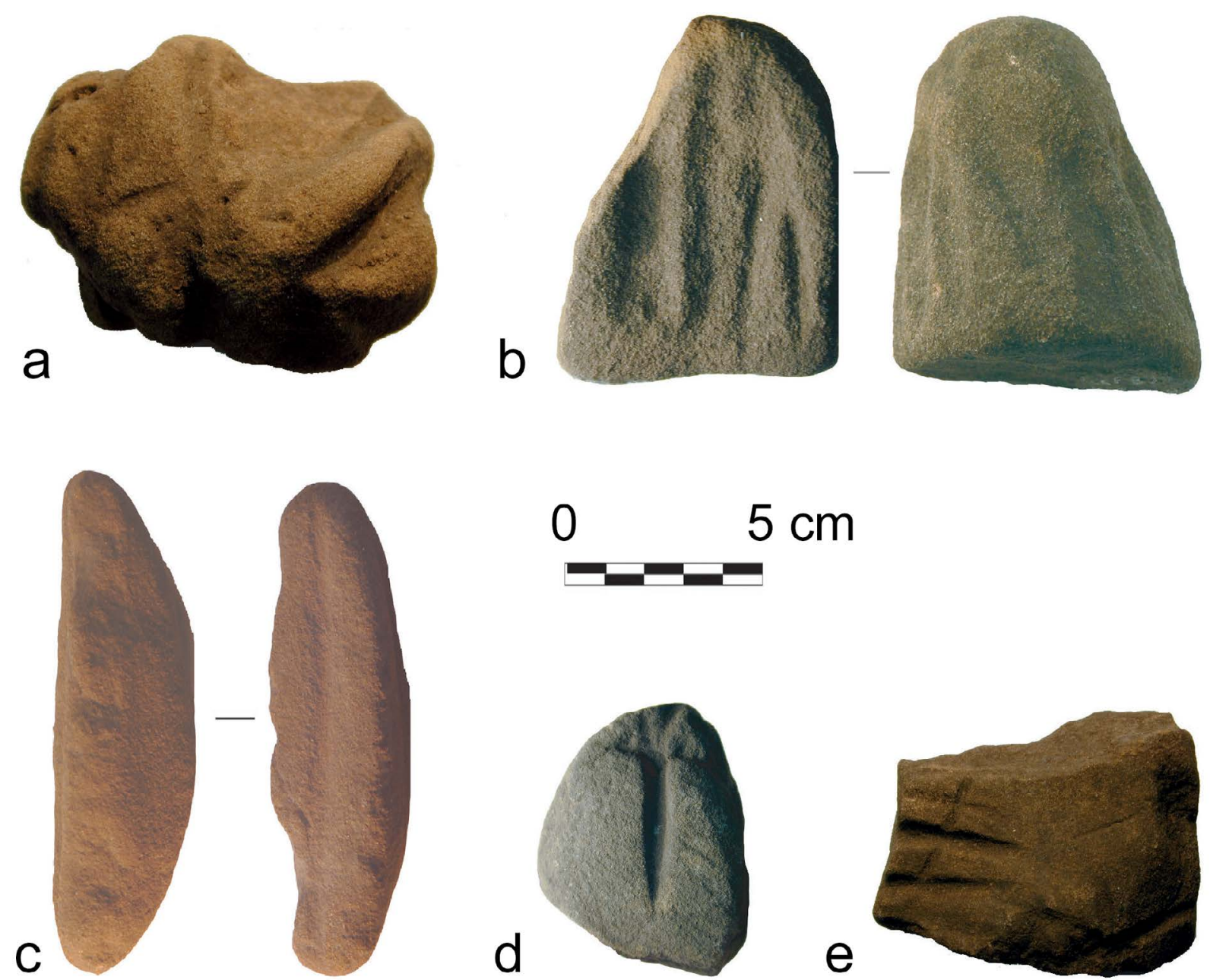

Figure 5. Different types of grooved abraders: a. and e. Bucy-le-Long "la Fosselle” (Aisne); b-c-d. Cuiry-lesChaudardes “les Fontinettes” (Aisne).
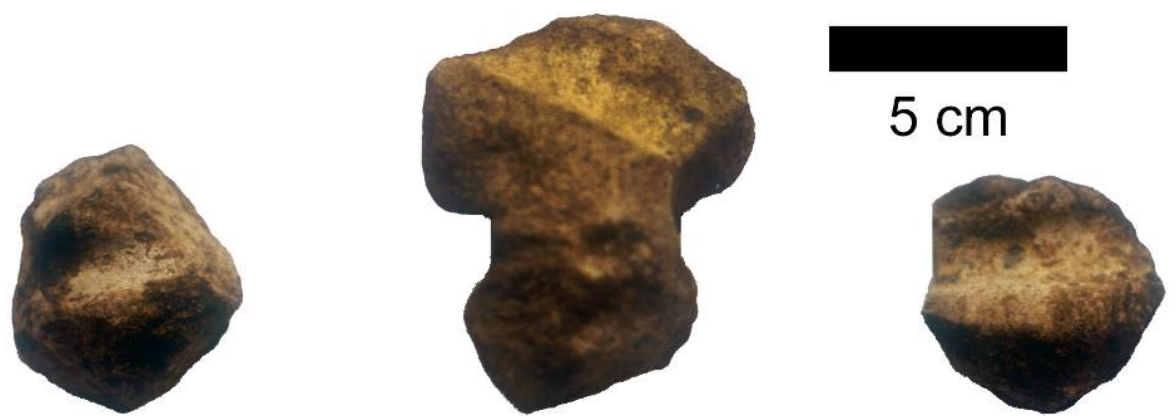

Figure 6. Marolles-sur-Seine "le Chemin de Sens": grooved abraders found with shell bead roughouts in the refuse of a workshop in a pit along an early Neolithic house

Made of moderately cohesive sandstones, these abraders show no traces of pre-forming. Up to three grooves were used on each abrader. The grooves are short but wide, and their widths (between 1 and $2 \mathrm{~cm}$ ) are comparable to each other morphologically and also correspond to one of the circular beads. The sides of the grooves are parallel, except at their ends where they appear to widen. Their section is more or less of open "U" shaped profile. They are sometimes delimited by a rim, polished in the continuity of the groove itself. Despite the lack of use-wear analysis on these abraders, their spatial association with shell and 
limestone bead clearly suggests a probable use in the production chaîne opératoire of limestone or shell beads.

Several studies have also been conducted on the emblematic bracelet production contexts in the Blicquy-Villeneuve-Saint-Germain culture. Several workshops have been recognized in two regions where schist is available. In Hesbaye, a workshop for bracelet production was identified on the settlement of Vaux-et-Borset (Caspar et al. 2005). In the Sarth region, on the border of the Armorican Massif, several workshops were discovered, sometimes directly associated with quarries (Marcigny et al. 1999; Giazzon et al. 2002; Gaumé 2007). On these sites, a complete lithic toolkit, composed of flint, sandstone and schist implements, were involved in the manufacture of bracelets, following two different chaînes opératoires. Within the toolkit, a series of grooved tools made of coarse sandstone have been identified. In the Sarth workshops, abraders displayed grooves of varied morphology, from linear to curvilinear, sometimes with pointed ends.

The grooves were either pre-formed or resulted from repeated use on the same part of the tool. One particularly large example of a grooved abrader $(2.6 \mathrm{~kg})$ was probably used in a lower (passive) position. Two grooves of semi-circular section are located on two opposite faces. The grooves measure on average $0.5 \mathrm{~cm}$ in depth, 1 to $2 \mathrm{~cm}$ in width, and 3.5 to $7.5 \mathrm{~cm}$ in length. The groove profiles of other abraders correspond to sections related either to the internal or external shape of the bracelets (Figure 4). The localization of these grooves implies a modification of the position of the tools during their use, while their morphology and depth sometimes imply long durations of use. The "lenticular" shape of the grooves is characteristic of the abrasion of the sides of the bracelets. On the most highly cemented sandstones, usewear is characterized by mechanical abrasion, together with a lighter crushing of the well individualized grains: These patterns are indicative of the abrasion of mineral matter. These abraders were undoubtedly used for the shaping and sharpening of elongated surfaces using a longitudinal or circular movement of abrasion (Hamon 2006: 131-132).

The second example comprises a grooved abrader found on the site of Betton "Pluvignon" (Brittany, France) (Blanchet et al. 2010). This abrader is one of sixteen abrading tools found in several pits within the settlement, among which three lower polishers and eight hand polishers were also identified. In fact, all these abraders share several characteristics: They were all shaped from the same fine Brioverian sandstone and show comparable macroscopic use-wear with very homogeneous surfaces (Figure 7). Consequently, the principal question posed by this assemblage is whether or not the tools were all involved in the same chaîne opératoires of production.

A large lower polisher (29x20x12cm; $5.2 \mathrm{~kg})$ shows six successive zones of polishing on its main surface, and several longitudinal grooves, together with three pointed ones, on its sides. Morphological and use-wear analysis of these grooves suggests the (re)-sharpening of points or edges of tools made from hard animal-derived materials. The eight hand abraders show two to four concave abrasion surfaces, in line with their being used with a longitudinal and semi-circular gesture. The regular deformation and depth of the working surfaces indicate that they had quite a long duration of use. Again, the use-wear traces suggest their use for the manufacture of tools made from hard animal-derived materials.

Finally, we shall consider the case of the grooved abrader made of less well-sorted sandstone. The longitudinal groove has a semi-circular section and convergent sides. Microscopic use-wear analysis shows that the grains remain well individualized, show irregular surfaces and are sometimes removed from the surfaces, along with regular longitudinal striations. By comparison of the experimental referential, this combination of traces clearly indicates that it was used for processing hard animal material. 


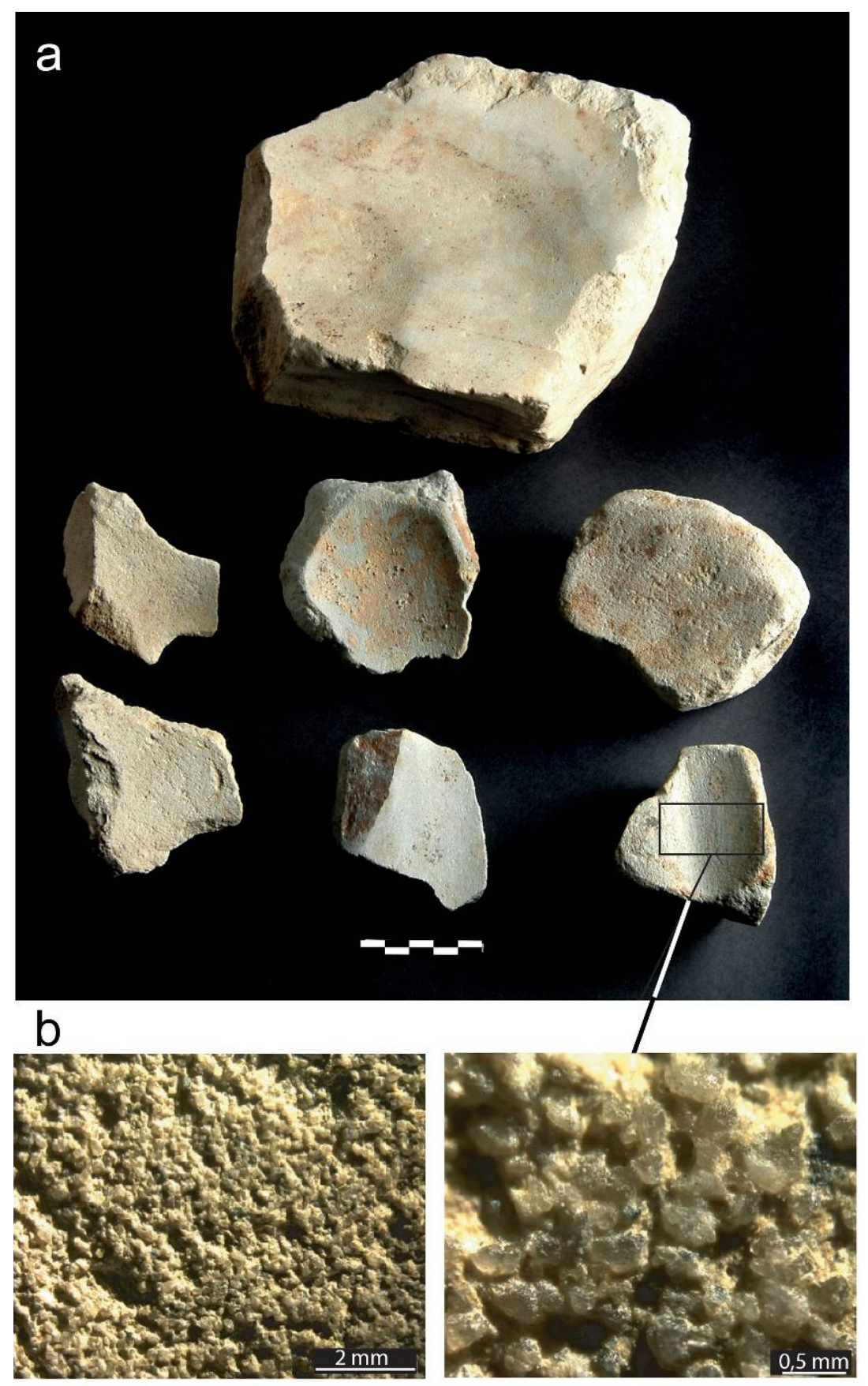

C
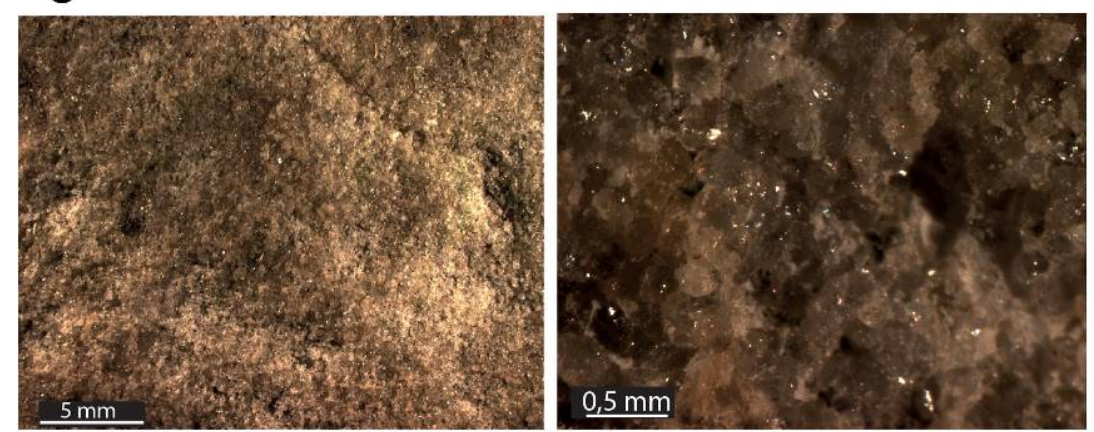

Figure 7. Abraders in coarse brioverien sandstone from the site of Betton "Pluvignon” (a) the use-wear observed on all these tools (b) are comparable to experimental surfaces used for fresh bone tool shaping by abrasion during one hour. Note in both cases the intermediate rate of levelling, well individualized grains, and slightly altered to microfractured surfaces (c). 
The analysis of these tools indicates that they were all involved in the shaping of different parts of bone tools, using different motions (linear back-and-forth, rotation, on flat surfaces). In this specific case, the grooved abrader is not an indicator of a specific activity, but corresponds to a specific stage within a more complete chaîne opératoires of transformation, in which other stone tools were required.

A third case study based on two of the six grooved abraders from the village of Ocquerre "la Rocluche", however, demonstrates that similarity in tool morphology does not always indicate a similar function (Hamon 2009). Two massive lower abraders show a combination of flat polishing zones and several grooves on their faces and sides (Figure 8). The first abrader is made of quite coarse sandstone, and features two groups of grooves on its main face and its end. Its primary face displays two main grooves, one with parallel sides and open " $u$ " section $(7.9 \times 0.8 \times 0.4 \mathrm{~cm})$ and the other with crossing sides $(4.2 \times 1.5 \times 3 \mathrm{~cm})$, together with two superficial oblique grooves $(3.4 \times 0.9 \times 0.2 \mathrm{~cm})$. On the distal end of the tool, a large lenticular and curvilinear groove with "open" semi-circular section was pre-formed by pecking. The use-wear analysis clearly shows that these grooves were used for the shaping of tools made from hard, animal-derived material (Figure 8a).

A second tool, consisting of a massive block of more than $12 \mathrm{~kg}$, features a large flat polishing zone together with up to nine grooves on its sides. The main working face $(38 \mathrm{~cm}$ long) is covered by homogeneous smoothing of the surface. Its side features no less than six long grooves, separated from each other by a smoothed rim. Three of these grooves are more or less rectilinear (8 to $12 \mathrm{~cm}$ long and up to $3 \mathrm{~cm}$ deep) and are composed of a series of concave alveoles with open profiles. Three other contiguous grooves are present (each forms part of a single longitudinal groove), which have a maximum length of $3.5 \mathrm{~cm}$ and a maximum depth of $7 \mathrm{~mm}$. The use-wear analysis of the grooves indicates a high degree of surface levelling and a certain density of micro-fracturation of the grains, which indicate by comparison with our experimental referential, that the tool was probably used for abrading a hard, mineral object (Figure 8b).

These two examples show that the association of a flat polished surface with longitudinal grooves on massive blocks may indicate that the abrader was used for different activities. In one case, the most plausible possibility is related to the shaping of bone tools while in the other, the polishing of stone adzes seems the most reliable hypothesis: Both activities were an important part in the technical system of early farmers.

\section{Discussion}

Based on the shared characteristics of grooved abraders, they show a low investment in their conception. This statement is based for most tools on the choice of small fragments of varied dimensions and shapes, generally showing no shaping of their general morphology or of their working surfaces. The intensive use of these fragments, sometimes with several grooves crossing each other, is another element to take into account. The only constraining criterion is the choice of the raw material which should possess specific properties: hardness, low cohesion and grain sorting.

The importance of the raw material criteria also explains the optimization of the blanks, even when the raw material is locally abundant, which is the case for most of the early Neolithic sites in the Aisne Valley, for example. Only one type of grooved abrader shows different features, which correspond to a specialized use (Allard et al. 2006). The "shaftstraightener" type is characterized by distinctive morphological and dimensional features. The specific investment put into this tool not only involves an adapted raw material but also fine shaping of its back, sides and pre-forming of its working surface. Because it requires specific stages of manufacture, it cannot be considered an expedient tool. The specific production 
stages of these tools are dictated by their function but probably also by a special status attached to them which was linked to their symbolic value.

\section{a}
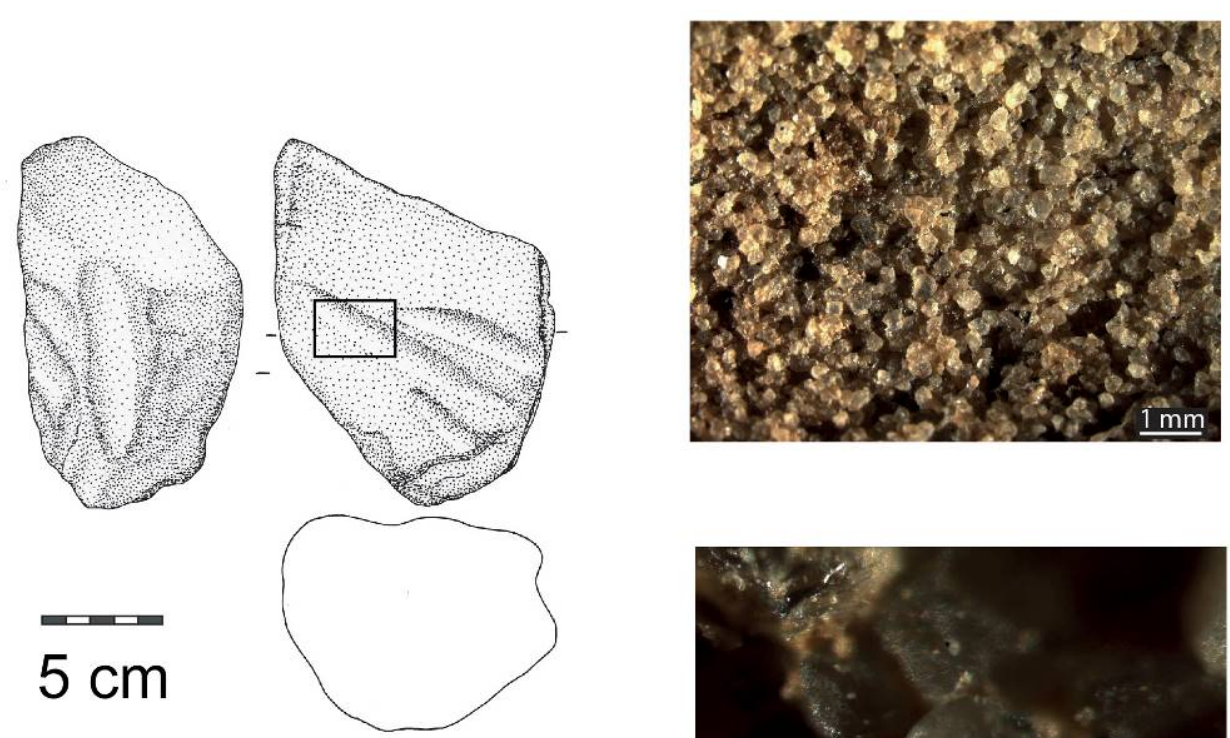

b
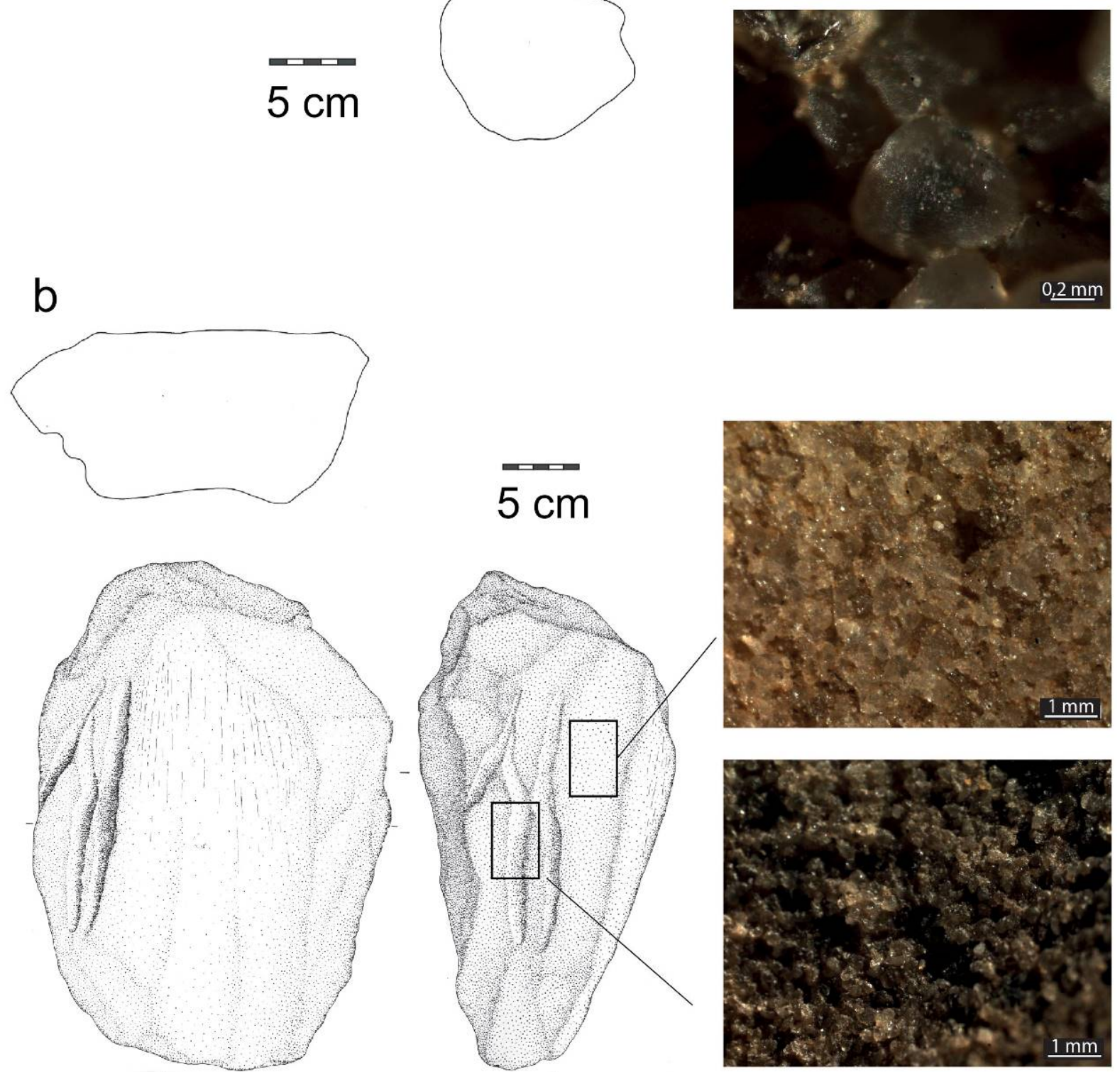

Figure 8. Flat and grooved massive abraders from the site of Ocquerre "la Rocluche": a. use-wear comparable to bone tool abrasion (well-individualized grains, microfractured to altered surface, moderate levelling); b. usewear comparable to hard mineral surface abrasion (high degree of levelling and microfracturing) (microphotos from Hamon 2009). 
The context of discovery and use of these tools throws light on their status within the technical system in a particular way. As highlighted by the examples presented above, abraders are generally found in domestic contexts: In the refuse pits adjacent to houses. Nevertheless, as indicated by the use-wear analysis and the context of the finds, they are generally not used alone, and often belong to "domestic" workshops. Moreover, their use is always related to specific stages in the processing of tools or ornaments. This makes them a good indicator of the existence of craft production which tended to be organized in specialized workshops.

These activities may have been occasional or more regular in frequency. They may have been practiced by occasional or specialized craftsmen in a specialized area within the domestic unit. In the case of the shaft straightener type, their deposition as offerings in tombs throughout the early Neolithic of Europe also stresses their special status (Pavlu \& Rulf 1991: 336 ; Farruggia 1992: 41). In particular, the question arises whether these tools were part of a specialised toolkit that was the private property of an individual. The tools may have been associated with the status of the user, if not the owner, during their lifetime and beyond in the afterlife.

Above all else, these examples highlight the fact that grooved abraders were used for many different parts of the technical system. Far from the widely accepted hypothesis that the grooved abraders were essentially used as wooden shaft straighteners, the use-wear analysis and archaeological association of items, reveal that they were closely associated with the manufacture of bone tools, stone adzes, schist bracelets and shell beads. These products all had high cultural value among the early Neolithic cultures of north-western Europe. The generalization of abrading and polishing techniques for the manufacture of a large part of the material culture represents one of the most important shifts characterizing early Neolithic contexts and was accompanied by two other phenomena.

First, the diversification of the abrading tools involved in these chaînes opératoires illustrates that specialization was taking place in the related techniques. Second, it suggests that there was growing specialization of the craftsmen themselves and a complexification of their know-how, even though the economic context in which they were working remained, at least partly, domestic. We could even go a step further by suggesting in a broader framework that the specialization of these results may offer us a renewed vision of the structuration of the activities within the domestic versus collective space, as proposed in other recent papers on the topic (Bostyn 2003: p. 267-279; Hachem \& Hamon 2014).

\section{Conclusion}

The technological study of grooved abraders found in the first Neolithic settlements in north-western Europe is particularly relevant for the identification of the increasing role of abrading techniques in a wide range of craft activities, from routine daily activities to those with high cultural value. This study demonstrates how the generalization of these techniques for the production of a wide range of objects, from tools to personal ornaments, was accompanied by a high degree of adaptation of these tools in several chaînes opératoires of production. In a sense, this highlights from a new perspective the high cultural value attached to the production of polished and abraded items at the beginning of the Neolithic. As such it contributes to the definition of a completely new technical paradigm and is one of the essential elements for defining the Neolithic.

\section{Acknowledgments}

Thanks go to E. Boitard, Inrap for drawing of Figure 8 and to H. Paitier, Inrap for the photos in Figures 3 and 7. 


\section{References}

Adams, J. 2002, Manual for a technological approach to ground stone analysis. Center for Desert Archaeology, Tucson, 320 p.

Adams, J., Delgado, S., Dubreuil, L., Hamon, C., Plisson, H., \& Risch, R. 2009, Functional analysis of macro-lithic artefacts. In: Non-flint Raw Material Use in Prehistory: Old Prejudices and New Direction, 15th UISPP congress, Lisbon-September 2006 (Sternke, F., Eigeland, L., \& Costa, L., Eds.), BAR International Series Vol. 1939, Archaeopress, Oxford: p. 43-66.

Allard, P., Hamon, C., Bonnardin, S., Cayol, N., Chartier, M., Coudart, A., Dubouloz, J., Gomart, L., Hachem, L., Ilett, M., Meunier, K., Monchablon, C., \& Thevenet, C. 2013, Linear Pottery domestic space: Taphonomy, distribution of finds and economy in the Aisne valley settlements. In: The Domestic Space in LBK Settlements (Hamon, C., Allard, P., \& Ilett, M., Eds.), Verlag Marie Leidorf GmbH, Rahden, Westfalien: p. 9-28.

Allard, P., Hamon, C., \& Sidera, I. 2006, Sophistication et adaptabilité des productions lithiques et osseuses du Rubané du Bassin parisien. In: Normes Techniques et pratiques sociales. De la simplicité des outillages pré et proto historiques, XXVIe rencontres internationales d'archéologie et d'histoire d'Antibes (Astruc, L., Bon, F., Léa, V., Milcent, P.-Y., \& Philibert, S., Eds.), Éditions Association pour la promotion et la diffusion des connaissances archéologiques, Antibes: p. 185-194. (in French) ("Sophistication and adaptability of lithic and bone productions in the Linerabandkeramik of the Paris basin”)

Augereau, A., \& Bonnardin, S. 1998, Marolles-sur-Seine "le Chemin de Sens" (Seine-etMarne) et la fabrication de la parure en calcaire au Néolithique ancien. Bulletin de la Société Préhistorique Française, 95(1): 23-39. (in French) ("Marolles-sur-Seine "le Chemin de Sens" (Seine-et-Marne), and the manufacture of limestone in the early Neolithic”). doi:10.3406/bspf.1998.10733

Aurenche, O., \& Koslowski, S.K. 1999, La naissance du Néolithique au Proche-Orient. Errance, Paris, 255 p. (in French) ("The birth of the Neolithic in the Near-East")

Balkan-Atli, N. 1994, La Néolithisation de l'Anatolie. Institut Français d'Études Anatoliennes d'Istanbul avec le concours du CNRS (Centre National de la Recherche Scientifique), De Boccard, Paris, 246 p. (in French) (“The Neolithisation of Anatolia”).

de Beaune, S. A. 2000, Pour une archéologie du geste. Broyer, moudre, piler. Des premiers chasseurs aux premiers agriculteurs. Centre National de la Recherche Scientifique (CNRS) Éditions, Paris, 231 p. (in French) ("For gesture archaeology. Grinding, milling and pounding. From the first hunters to the first farmers").

Billard, C., Bostyn, F., Hamon, C., \& Meunier, K. 2014, L'habitat du Néolithique ancien de Colombelles « Le Lazzaro » (Calvados). Mémoire Vol. 58, Société Préhistorique Française, Paris, 408 p. (in French) ("The early Neolithic village of Colombelles "Le Lazzaro” (Calvados) ”). 
Blanchet, S., Forre, P., Fromont, N., Hamon, C., \& Hamon, G. 2010, Un habitat du Néolithique ancien à Betton « Pluvignon » (Ille-et-Villaine): Présentation synthétique des différents ensembles mobiliers. In: Quoi de neuf à l'ouest: Cultures, réseaux et échanges des premières sociétés néolithiques à leur expansion, Actes du 28e colloque interrégional sur le Néolithique (Marcigny, C., San Juan, G., \& Riche, C., Eds.), Presses Universitaires de Rennes, Rennes, p. 15-29. (in French) ("An early Neolithic village in Betton "Pluvignon” (Ille-et-Villaine)”)

Bolus, M. 2012, Schleifsteine mit Rille (Pfeilschaftglätter). In: Steinartefakte. Vom Altpaläolithikum bis in die Neuzeit (Floss, H., Ed.), Kerns Verlag, Tübingen: p. 525534. (in German) (“Abraders with grooves”)

Bostyn, F. 2003, Néolithique ancien en Haute Normandie: Le village Villeneuve-SaintGermain de Poses "Sur la Mare" et les sites de la boucle du Vaudreuil. Travaux de la Société Préhistorique Française Vol. 4, Société Préhistorique Française, Paris, 342 p. (in French) ("Early Neolithic in Haute Normandie: The Villeneuve-Saint-Germain village of Poses "Sur la Mare" and the sites of the Vaudreuil meandre")

Camps-Fabrer, H. 1960, Parure des temps préhistoriques en Afrique du Nord. Lybica 8: 102165. (in French) ("Prehistoric ornaments in northern Africa")

Caspar, J.-P., Burnez-Lanotte, L., \& Vanguestaine, M. 2005, Technologie des anneaux en schiste dans le groupe de Blicquy/Villeneuve-Saint-Germain à Vaux-et-Borset (Hesbaye, Belgique): Interférences de sous-systèmes techniques. Bulletin de la Société Préhistorique Française, 102(3): 551-596. (in French) ("Technology of schist rings des anneaux in the Blicquy/Villeneuve-Saint-Germain group at Vaux-et-Borset (Hesbaye, Belgique)”). doi:10.3406/bspf.2005.13142

Christensen, M. \& Valla, F. 1999, Pour relancer un débat: Que sont les pierres à rainure du Natoufien Proche-Oriental? Bulletin de la Société Préhistorique Française, 96(2): 247252. (in French) ("To revive the debate: What are natoufian near-eastern grooved stones”) doi:10.3406/bspf.1999.10947

Dunn, E.J. 1931, The Bushman. Charles Griffin \& Company, London, 130 p.

Farruggia, J.-P. 1992, Les outils et les armes en pierre dans le rituel funéraire du Néolithique danubien. BAR International Series Vol. 581, Archaeopress, Oxford, 456 p. (in French) ("Stone tools and weapons in the funerary practices of the danubian Neolithic")

Flenniken, J. J., \& Ozbun, T. L. 1988, Experimental analysis of plains grooved abraders. Plains Anthropologist, 33(119): 37-52. URL: http://www.jstor.org/stable/25668735

Gaumé, E. 2007, Les dépôts de palets et de disques en schiste du Néolithique ancien: Des stocks de produits semi-ouvrés? Oui, mais encore (Précisions pratiques avec le savoirfaire ancestral des fendeurs manuels d'ardoise dans les Massifs armoricain et ardennais). Bulletin de la Société Préhistorique Française, 104(1): 55-61. (in French) ("Schist discs hoards in the early Neolithic: Stocks of half transformed products. So what? Practical precisions on an ancient know-how on the manual splitting of slate in the Armoric and Ardennes massifs”) doi:10.3406/bspf.2007.13647

Gaussen, J., \& Gaussen, M. 1988, Les ateliers à pierres à rainures. In: Le Tilemsi Préhistorique et ses abords. Sahara et Sahel malien (Gaussen, J., \& Gaussen, M., Eds.). Cahiers du Quaternaire Vol. 11, Centre National de la Recherche Scientifique (CNRS) Centre Régional de Publication de Bordeaux, Paris: p. 189-191. (in French) (“Grooved abraders workshops. The prehistoric Tilemsi and its margins”) 
Giazzon, D., Marcigny, C., \& Ghesquiere, E. 2002, Un nouveau site de production de bracelets en schiste dans le nord de la Sarthe: Arçonnay "le Parc Saint-Gilles". Bulletin de la Société Préhistorique Française, 99(4): 825-828. (in French) (“A new site of schist bracelets production in northern Sarth: Arçonnay "le Parc Saint-Gilles”). doi:10.3406/bspf.2006.13395

Gob, A., \& Pirnay, L. 1980, Utilisation des galets et plaquettes dans le Mésolithique du bassin de l'Ourthe. Études et Recherches Archéologiques de l'Université de Liège Serie A/5, Liège: p. 1-25. (in French) ("The use of cobbles and slabs in the Mesolithic of the Ourthe Basin")

Gomart, L., Hachem, L., Hamon, C., Giligny, F., \& Ilett, M. 2015, Household integration in Neolithic villages: A new model for the Linear Pottery Culture in west central. Journal of Anthropological archaeology, 40: 230-249. doi:10.1016/j.jaa.2015.08.003

Hachem, L., \& Hamon, C. 2014, Linear pottery household organization: An economic model. In: Early Farmers: The View from Archaeology and Science (Whittle, A., \& Bickle, P., Eds.), Proceedings of the British Academy Vol. 198, British Academy, London: p. 159180.

Hamon, C. 2006, Broyage et abrasion au Néolithique ancien. Caractérisation technique et fonctionnelle des outillages en grès du Bassin parisien. BAR International Reports Series Vol. 1551, Archaeopress, Oxford, 342 p. (in French) (“Grinding and abrading during the early Neolithic. Technical and functional characterization of sandstone tools in the Paris Basin”)

Hamon, C. 2008, Functional analysis of stone grinding and polishing tools from the earliest Neolithic of north-western Europe. Journal of Archaeological Science, 35(6): 15021520. doi:10.1016/j.jas.2007.10.017

Hamon, C. 2009, L’outillage en grès. In: Le Néolithique ancien dans la Basse vallée de la Marne et ses affluents: Un site d'habitat producteur de lames en silex tertiaire de la fin du Villeneuve-Saint-Germain à Ocquerre (Seine-et-Marne) (Praud, I., Bostyn, F., Dietsch-Sellami, M.F., Hamon, C., Lanchon, Y., \& Michel, L., Eds.), Travaux de la Société Préhistorique Française 9, Société Préhistorique Française, Paris, p. 77-97 (in French) ("The early neolithic in the Marne valley and its tributaries: A production settlement of tertiary flint axes at the end of the Villeneuve-Saint-Germain à Ocquerre (Seine-et-Marne)")

Hamon, C., \& Goemaere, E. 2007, Outils de broyage et outils d’abrasion en contexte rubané de Hesbaye: Premiers résultats d'une analyse techno-fonctionnelle. Notae Praehistoricae 27: 109-119. (in French) ("Grinding and abrading tools in the Linear pottery from Hesbaye: First results of a techno-functional analysis”)

Huard, P. 1966, Pierres à rainures du Nord Tibesti. Bulletin de la Société Préhistorique Française, 63: 158-159. (in French) ("Grooved stones in northern Tibesti”). doi:10.3406/bspf.1966.8908

Loftus, J. 1982, Ein verzierter Pfeilschaftglätter von Fläche 64/74-73/78 des spätpaläolithischen Fundplatzes Niederbieber/Neuwieder Becken. Archäologisches Korrespondenzblatt, 12: 313-316. (in German) (“A decorated shaft straightener”) 
Marcigny, C., Guesquiere, E., Giazzon, D., \& Gaume, E. 1999, Un site de production de parures en schiste dans le Nord du département de la Sarthe à Champfleur "Bois de Barrée". Bulletin de la Société Préhistorique Française, 96(3): 635-648. (in French) (“A production site of schist ornaments in the north of the Sarth department in Champfleur “Bois de Barrée””). doi:10.3406/bspf.1999.11219

Molist, M., Bofill, M., Ortiz, A., \& Taha, B., 2013, Grooved stones and other macrolithic objects with incised decoration from the PPNB at Tell Halula (Syria, Middle Euphrates Valley). In: Stone Tools in Transition: From Hunter-Gatherers to Farming Societies in the Near East (Borrell, F., Ibáñez, J. J., \& Molist, M., Eds.), Bellaterra, Universitat Autònoma de Barcelona. Servei de Publicacions, Barcelona, p. 421-434.

Pavlu, I., \& Rulf, J. 1991, Stone industry from the Neolithic site of Bilany. Pamatky Archeologicke, 82: 330-365.

Rosenberg D., Kaufman D., Yeshurun R., \& Weinstein-Evron M. 2012, The broken record: The Natufian groundstone assemblage from el-Wad Terrace (Mount Carmel, Israel) Attributes and their interpretation. Eurasian Prehistory, 9: 93-128.

Rozoy, J.-G. 1978, Les derniers chasseurs. L'Epipaléolithique en France et en Belgique. Essai de synthèse. 3 Bände, Selbstverlag, Charleville, 1500 p. (in French) ("The last hunter-gatherers. Epipalaeolithic in France and Belgium. A synthesis”)

Solecki R.L., \& Solecki, R.S. 1970, Grooved stones from Zawi Chemi Shanidar, a Protoneolithic site in Northern Iraq. American Anthropologist, 72(4): 831-841. doi:10.1525/aa.1970.72.4.02a00080

Usacheva, I.V. 2013, On the function of "grooved stones”. Archaeology Ethnology \& Anthropology of Eurasia, 41(4): 58-64. doi:10.1016/j.aeae.2014.07.007 